\title{
Pemodelan Arus Stator Motor Induksi Tiga Fasa dengan Metode Gear
}

\author{
NANANG MULYONO, DWI SEPTIYANTO, SUYANTO \\ Teknik Elektro Politeknik Negeri Bandung, Indonesia \\ Email : nanang.mulyono@polban.ac.id \\ Received 1 April 2020| Revised 27 April 2020| Accepted 1 Juni 2020
}

\begin{abstract}
ABSTRAK
Penelitian ini mendiskusikan proses dan hasil implementasi pemodelan arus stator motor induksi tiga fasa dengan metode Gear. Tujuan penelitian ini adalah menghasilkan program simulasi motor listrik yang mampu menampilkan karakteristik dinamik arus stator motor induksi tiga fasa. Metodologi penyelesaian penelitian ini dimulai dari ide dasar, studi literature, perancangan, pembuatan dan pengujian software. Penerapan metode Gear dibuat dengan bahasa Python. Hasil simulasi arus stator yang diamati pada kondisi transien dan tunak, yaitu nilai maksimum, nilai minimum, waktu transisi dan nilai peak-to-peak. Hasil simulasi tersebut dibandingkan dengan hasil simulasi menggunakan modul solver ODE15 yang tersedia pada Matlab. Simulator yang dibuat dapat mensimulasikan perilaku dinamik motor induksi tiga fasa dengan perbedaan 1,5\%, 0,93\% dan 1,5\% secara berturut-turut untuk arus stator fasa-a, arus stator fasa-b dan arus stator fasa-c.
\end{abstract}

Kata kunci: model dinamik, motor induksi, metode Gear, ODE15

\begin{abstract}
This study discusses the process and results of implementing the stator current modeling of the three-phase induction motor using the Gear method. This study aims to produce an electric motor simulation program that can display the dynamic characteristics of the stator current of a three-phase induction motor. The methodology of completing this research is the basic idea, literature study, design, creation, and software testing. The application of the Gear method is made with the Python programming language. Stator current simulation results are observed in transient and steady conditions, namely the maximum value, minimum value, transition time, and peak-to-peak value. The simulation results are compared with the simulation results using the ODE15 solver module available in Matlab. The simulator created can simulate the dynamic behavior of the stator current of a three-phase induction motor with a difference of $1.5 \%, 0.93 \%$, and $1.5 \%$ respectively for phase-a, phase- $b$, and phase-c.
\end{abstract}

Keywords: dynamic model, induction motor, Gear method, ODE15 
Mulyono, dkk

\section{PENDAhUluan}

Karakteristik dinamik motor listrik merupakan salah satu pertimbangan dalam pengujian sistem kendali motor listrik. Pengujian-pengujian eksprimental awal yang dilakukan secara konvensional dengan menggunakan motor secara real pada umumnya akan menimbulkan sejumlah kendala uji yang kurang menguntungkan. Cara konvensional tersebut membutuhkan biaya yang mahal, terutama untuk mesin berkecepatan tinggi atau besar (Boldea, dkk, 2001). Simulasi dinamis pada proses perancangan sistem penggerak motor memainkan peran penting dalam pra-pengujian sistem penggerak, menemukan kemungkinan kesalahan desain, atau mencegah kemungkinan bug/cacat yang dapat dipenuhi setelah pembuatan. Hal tersebut tergantung pada model dinamis dari motor induksi yang diperlukan dan digunakan (Kocabas, dkk, 2011) (Aleck, 2017) (Phukon, dkk, 2015).

Bélanger (Bélanger, dkk, 2010) telah melakukan penelitian dan mengklasifikasikan digital simulator seperti Rapid Control Prototyping (RCP), Hardware-in-the-Loop (HIL) dan Software in the Loop (SIL). HIL memungkinkan untuk digunakan sebagai alat uji berbagai kontroler ketika objek fisik motor tidak tersedia. Mulyono (Mulyono, dkk, 2018) telah mengimplementasikan model dinamik motor induksi tiga fasa berbasis metode Runge-Kutta orde empat dan raspberry pi. Simulator tersebut mampu menghasilkan data arus stator dan putaran rotor dengan pola grafiknya relatif sama dengan hasil simulasi menggunakan Matlab. Tetapi memiliki perbedaan lebih kecil dari $11 \%$ dan $14 \%$ untuk masing-masing besaran arus stator dan putaran rotor. Selain itu, terjadi juga kegagalan mendapatkan solusi ketika interval waktu yang diterapkan pada solver Runge-Kutta orde empat sebesar 0,1 detik. Tetapi ketika interval waktu yang diberikan 0,0001 detik, solver yang dibuat mampu memberikan solusi. Oleh karena itu terindikasi model dinamik motor induksi yang digunakan merupakan sistem persamaan diferensial stiff.

Persamaan diferensial stiffsering terjadi pada studi kinetik kimia, sirkuit listrik, vibrasi, sistem kendali dan lain-lain (Omale, dkk, 2014). Persamaan diferensial stiff merupakan permasalahan metode eksplisit tidak dapat bekerja dan tidak stabil secara numerik kecuali pada interval yang sangat kecil (Esfandiari, 2017) (Omale, dkk, 2014). Jenis persamaan diferensial tersebut sifatnya tidak unik dan relatif sulit diidentifikasi sejak dini. Permasalahan stiff numeric tidak dapat diselesaikan dengan solver konvensional (Rath, dkk, 2017). Metode Runge-Kutta orde empat merupakan metode untuk menyelesaikan persamaan diferensial non-stiff (Kulikov, 2013) (Shampine, dkk, 1979). Jika metode non-stiff digunakan untuk menyelesaikan persamaan diferensial stiff (permasalahan nilai awal), maka solver tersebut membutuhkan waktu sangat lama untuk menyediakan solusi / memberikan solusi yang tidak akurat / solver gagal menyediakan solusi (Omale, dkk, 2014). Metode multi-step yang popular untuk permasalahan stiff yaitu BDF (Backward Differentiation Formulae). Metode BDF dikenal juga sebagai metode Gear. BDF merupakan metode implisit yang melibatkan berbagai formula interpolasi (Rahmouni, dkk, 2017).

Rahmouni (Rahmouni, dkk, 2017) telah melakukan kajian kestabilan transien pada jaringan sistem tenaga 39-bus. Kajian terebut menggunakan metode Gear dan Block untuk menyelesaikan persamaan deferensial dari model jaringan sistem tenaga 39-bus. Hasil simulasi dari kedua metode tersebut dibandingkan dengan metode Runge-Kutta orde empat. Hasil simulasi menggunakan metode Gear dan Block menunjukkan hasil yang akurat. Metode Gear membutuhkan $28 \%$ dari waktu komputasi metode Runge-Kutta, sedangkan metode Block membutuhkan waktu $25 \%$ dari waktu komputasi metode Runge-Kutta. Penelitian yang membahas pemodelan dan simulasi motor induksi telah banyak dilakukan seperti yang dilakukan oleh Bora dan timnya (Boora, dkk, 2013), Dorjsuren dan timnya (Dorjsuren, dkk, 2015), Mengha dan timnya (Menghal, dkk, 2014) dan lain lain. 
Tujuan penelitian ini adalah menghasilkan program simulasi motor listrik yang mampu menampilkan karakteristik dinamik arus stator motor induksi 3 fasa berbasiskan metode Gear dan bahasa Python sesuai dengan hasil simulasi berbasis modul solver ODE15 pada Matlab.

\section{METODE GEAR DAN MODEL DINAMIK MOTOR INDUKSI TIGA FASA}

\subsection{Metode Gear}

Metode multi-step yang popular untuk permasalahan stiff yaitu BDF (Backward Differentiation Formulae). Rumus BDF merupakan fungsi implisit dan biasanya diimplementasikan bersama dengan metode Newton yang dimodifikasi untuk menyelesaikan sistem nonlinear pada setiap langkah waktu. Metode backward differentiation memiliki bentuk umum seperti Persamaan (1) (Rahmouni, dkk, 2017).

$$
\sum_{i=0}^{p} \alpha_{j} y_{n-i}=h \beta f\left(t_{n}, y_{n}\right)
$$

Dengan $a_{i}, \beta$ merupakan koefisien untuk formula $B D F p$-step, nilainya seperti Tabel 1 . Metode diferensiasi mundur harus digunakan bersama-sama dengan prediktor karena metode tersebut implisit. Metode Gear merupakan metode one-step yang diperoleh dari resultan pasanga multistep yaitu prediktor dan korektor. Metode tersebut memungkinkan terjadinya perubahan lokal dari urutan metode dan ukuran mesh. Metode Gear dirumuskan seperti Persamaan (2).

$$
y_{n+1}=\sum_{i=0}^{p-1} \alpha_{j} y_{n-i}+h \beta f\left(t_{n+1}, x_{n+1}\right)
$$

Metode Gear orde empat dirumuskan seperti pada Persamaan (3).

$$
y_{n+1}=h \frac{12}{25} f_{n+1}+\frac{48}{25} x_{n}-\frac{36}{25} x_{n-1}+\frac{16}{25} x_{n-2}-\frac{3}{25} x_{n-3}
$$

Tabel 1. Koefisien Metode P-step BDF

\begin{tabular}{|c|c|c|c|c|c|c|}
\hline $\mathbf{P}$ & $\boldsymbol{\beta}$ & $\mathbf{a}_{\mathbf{0}}$ & $\mathbf{a}_{\mathbf{1}}$ & $\mathbf{a}_{\mathbf{2}}$ & $\mathbf{a}_{\mathbf{3}}$ & $\mathbf{a}_{\mathbf{4}}$ \\
\hline 1 & 1 & 1 & & & & \\
\hline 2 & $\frac{2}{3}$ & $\frac{4}{3}$ & $-\frac{1}{3}$ & & & \\
\hline 3 & $\frac{6}{11}$ & $\frac{18}{11}$ & $-\frac{9}{11}$ & $\frac{2}{11}$ & & \\
\hline 4 & $\frac{12}{25}$ & $\frac{48}{25}$ & $-\frac{36}{25}$ & $\frac{16}{25}$ & $-\frac{3}{25}$ & \\
\hline 5 & $\frac{60}{137}$ & $\frac{300}{137}$ & $-\frac{300}{137}$ & $\frac{200}{137}$ & $-\frac{75}{137}$ & $-\frac{12}{137}$ \\
\hline
\end{tabular}

Ketika ukuran langkahnya konstan $h$, berorde $k$, dan langkahnya dari $\left(t_{n}, y_{n}\right)$ ke $\left(t_{n+1}, y_{n+1}\right)$ maka $\mathrm{BDF}_{\mathrm{k}}$ dirumuskan seperti Persamaan (4).

$$
\sum_{m=1}^{k} \frac{1}{m} \nabla^{m} y_{n+1}-h F\left(t_{n+1}, y_{n+1}\right)=0
$$

$B D F$ merupakan implicit integrator oleh karena itu Algebraic equation $\mathrm{y}_{\mathrm{n}+1}$ diselesaikan dengan iterasi. Nilai awal untuk iterasi direkomendasikan seperti Persamaan (5) (Shampine, dkk, 1997) (Griffiths, 2016).

$$
y_{n+1}^{(0)}=\sum_{i=0}^{k} \frac{1}{m} \nabla^{m} y_{n}
$$




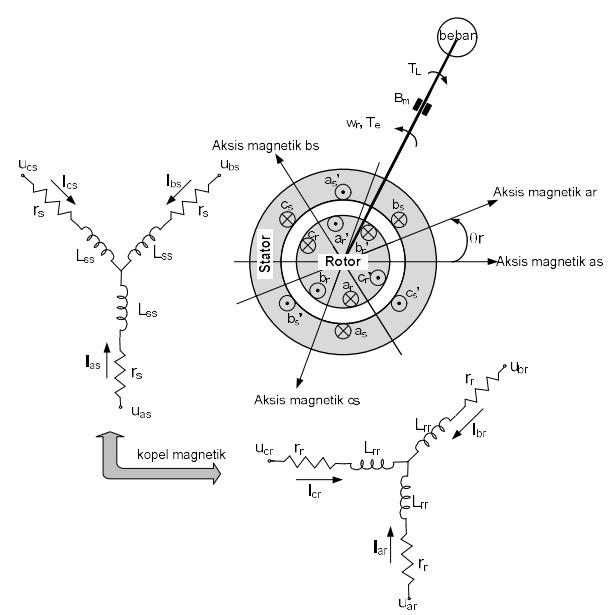

Gambar 1. Motor Induksi 3 Fasa Simetris (Mulyono, dkk, 2018)

\subsection{Model Dinamik Motor Induksi Tiga fasa}

Lyshevski dan Mulyono (Lyshevski, 2008) (Mulyono, dkk, 2018) menjelaskan model dinamik motor induksi 3 fasa berbasis pada sirkuit elektromagnetik seperti Gambar 1 dengan belitan stator dan rotornya dikonfigurasi bintang. Berbasis pada Gambar 1, persamaan tegangan pada belitan stator dan rotor, arus stator dan rotor serta flux linkage dapat diperoleh dengan menggunakan hukum tegangan Kirchhoff serta dengan menerapkan hukum Newton dan prinsip co-energy untuk memperoleh persamaan torka, maka persaman model dinamik motor induksi diperoleh dalam bentuk persamaan diferensial Cauchy seperti Persamaan (6) sampai dengan Persamaan (35). Parameter-parameternya, yaitu :

$P \quad$ jumlah kutub [-]

$r_{s} \quad$ resistansi belitan Stator $[\Omega]$

$r_{r} \quad$ resistansi belitan Rotor $[\Omega]$

$\mathrm{L}_{\mathrm{ms}} \quad$ induktansi bersama/mutual Stator-Rotor $[\mathrm{H}]$

$L_{l r}^{\prime} \quad$ induktansi bocor $[\mathrm{H}]$

$\mathrm{B}_{\mathrm{m}} \quad$ viscous Friction Coefficient $[-]$

J momen inersia motor $\left[\mathrm{kg} \mathrm{m}^{2}\right]$

$\mathrm{T}_{\mathrm{L}} \quad$ torsi beban $[\mathrm{N}-\mathrm{m}]$

Freq frekuensi dari tegangan yang di terapkan $[\mathrm{Hz}]$

$\mathrm{u}_{\text {as }}$ tegangan fasa pada belitan stator-as [V]

$\mathrm{u}_{\mathrm{bs}}$ tegangan fasa pada belitan stator-bs [V]

$\mathrm{u}_{\mathrm{cs}} \quad$ tegangan fasa pada belitan stator-cs [V]

$\mathrm{u}_{\mathrm{ar}}$ tegangan fasa pada belitan rotor-ar [V]

$\mathrm{ubr}_{\mathrm{br}}$ tegangan fasa pada belitan rotor-br [V]

$\mathrm{u}_{\mathrm{cr}} \quad$ tegangan fasa pada belitan rotor-cr [V]

$i_{\text {as }} \quad$ arus pada belitan stator-as $[\mathrm{A}]$

ibs arus pada belitan stator-bs [A]

$\mathrm{i}_{\mathrm{cs}} \quad$ arus pada belitan stator-cs $\quad[\mathrm{A}]$

$i_{a r}^{\prime} \quad$ arus pada belitan rotor-ar [A]

$i_{b r}^{\prime} \quad$ arus pada belitan rotor-br $\quad[\mathrm{A}]$

$i_{c r}^{\prime} \quad$ arus pada belitan rotor-cr $\quad[\mathrm{A}]$

$\omega_{\mathrm{r}} \quad$ kecepatan sudut [rad/detik]

$\theta_{\mathrm{r}} \quad$ sudut fasa [rad]

$\mathrm{T}_{\mathrm{e}} \quad$ torsi rotor $[\mathrm{N}-\mathrm{m}]$

$$
\boldsymbol{Y}=\frac{1}{L_{\Sigma L}}(\boldsymbol{A} \boldsymbol{X}+\boldsymbol{B} \boldsymbol{X}+\boldsymbol{C} \boldsymbol{X}+\boldsymbol{D} \boldsymbol{U})
$$




\section{Dengan}

$$
Y=\left[\begin{array}{c}
\frac{d i_{a s}}{d t} \\
\frac{d i_{b s}}{d t} \\
\frac{d i_{c s}}{d t} \\
\frac{d i_{a r}^{\prime}}{d t} \\
\frac{d i_{b r}^{\prime}}{d t} \\
\frac{d i_{c r}^{\prime}}{d t}
\end{array}\right] \quad X=\left[\begin{array}{l}
i_{a s} \\
i_{b s} \\
i_{c s} \\
i_{a r}^{\prime} \\
i_{b r}^{\prime} \\
i_{c r}^{\prime}
\end{array}\right] \quad U=\left[\begin{array}{l}
u_{a s} \\
u_{b s} \\
u_{c s} \\
u_{a r}^{\prime} \\
u_{b r}^{\prime} \\
u_{c r}^{\prime}
\end{array}\right]
$$

A, B, C dan D pada Persamaan (6) merupakan matriks 6x6 seperti Persamaan (8) - (11).

$$
\begin{gathered}
A=\left[\begin{array}{llllll}
A_{11} & A_{12} & A_{13} & A_{14} & A_{15} & A_{16} \\
A_{21} & A_{22} & A_{23} & A_{24} & A_{25} & A_{26} \\
A_{31} & A_{32} & A_{33} & A_{34} & A_{35} & A_{36} \\
A_{41} & A_{42} & A_{43} & A_{44} & A_{45} & A_{46} \\
A_{51} & A_{52} & A_{53} & A_{54} & A_{55} & A_{56} \\
A_{61} & A_{62} & A_{63} & A_{64} & A_{65} & A_{66}
\end{array}\right] \\
B=\left[\begin{array}{llllll}
B_{11} & B_{12} & B_{13} & B_{14} & B_{15} & B_{16} \\
B_{21} & B_{22} & B_{23} & B_{24} & B_{25} & B_{26} \\
B_{31} & B_{32} & B_{33} & B_{34} & B_{35} & B_{36} \\
B_{41} & B_{42} & B_{43} & B_{44} & B_{45} & B_{46} \\
B_{51} & B_{52} & B_{53} & B_{54} & B_{55} & B_{56} \\
B_{61} & B_{62} & B_{63} & B_{64} & B_{65} & B_{66}
\end{array}\right] \\
C= \\
D=\left[\begin{array}{llllll}
C_{11} & C_{12} & C_{13} & C_{14} & C_{15} & C_{16} \\
C_{21} & C_{22} & C_{23} & C_{24} & C_{25} & C_{26} \\
C_{31} & C_{32} & C_{33} & C_{34} & C_{35} & C_{36} \\
C_{41} & C_{42} & C_{43} & C_{44} & C_{45} & C_{46} \\
C_{51} & C_{52} & C_{53} & C_{54} & C_{55} & C_{56} \\
C_{61} & C_{62} & C_{63} & C_{64} & C_{65} & C_{66}
\end{array}\right] \\
{\left[\begin{array}{llllll}
D_{11} & D_{12} & D_{13} & D_{14} & D_{15} & D_{16} \\
D_{21} & D_{22} & D_{23} & D_{24} & D_{25} & D_{26} \\
D_{31} & D_{32} & D_{33} & D_{34} & D_{35} & D_{36} \\
D_{41} & D_{42} & D_{43} & D_{44} & D_{45} & D_{46} \\
D_{51} & D_{52} & D_{53} & D_{54} & D_{55} & D_{56} \\
D_{61} & D_{62} & D_{63} & D_{64} & D_{65} & D_{66}
\end{array}\right]}
\end{gathered}
$$

Dengan elemen-elemen matrik $A, B, C$ dan $D$ sebagai berikut:

a. $A_{45}, A_{46}, A_{54}, A_{56}, A_{64}, A_{65}, A_{14}, A_{15}, A_{16}, A_{24}, A_{25}, A_{26}, A_{3} 4, A_{35}, A_{36}, A_{41}, A_{42}, A_{43}, A_{51}, A_{52}, A_{53}$, $A_{61}, A_{62}, A_{63}$ bernilai nol

b. $\mathrm{B}_{11}, \mathrm{~B}_{12}, \mathrm{~B}_{13}, \mathrm{~B}_{21}, \mathrm{~B}_{22}, \mathrm{~B}_{23}, \mathrm{~B}_{31}, \mathrm{~B}_{32}, \mathrm{~B}_{33}, \mathrm{~B}_{44}, \mathrm{~B}_{45}, \mathrm{~B}_{46}, \mathrm{~B}_{54}, \mathrm{~B}_{55}, \mathrm{~B}_{56}, \mathrm{~B}_{64}, \mathrm{~B}_{65}, \mathrm{~B}_{66}$ bernilai nol

c. $\mathrm{C}_{11}, \mathrm{C}_{22}, \mathrm{C}_{33}, \mathrm{C}_{44}, \mathrm{C}_{55}, \mathrm{C}_{66}$ bernilai nol 
Elemen-elemen matrik A, B, C dan D yang tidak sama dengan nol seperti Persamaan (12) (32).

$$
\begin{aligned}
& \mathrm{A}_{11}=\mathrm{A}_{22}=\mathrm{A}_{33}=\mathrm{A}_{44}=\mathrm{A}_{55}=\mathrm{A}_{66}=-r_{s} L_{\Sigma m} \\
& \mathrm{~A}_{12}, \mathrm{~A}_{13}, \mathrm{~A}_{21}, \mathrm{~A}_{23}, \mathrm{~A}_{31}, \operatorname{dan} \mathrm{A}_{32}=-\frac{1}{2} r_{s} L_{\mathrm{ms}} \\
& \mathrm{B}_{14}=\mathrm{B}_{25}=\mathrm{B}_{26}=r_{r} L_{\mathrm{ms}} \cos \theta_{r} \\
& \mathrm{~B}_{41}=\mathrm{B}_{52}=\mathrm{B}_{63}=r_{s} L_{\mathrm{ms}} \cos \theta_{r} \\
& \mathrm{~B}_{15}=\mathrm{B}_{26}=\mathrm{B}_{34}=r_{r} L_{\mathrm{ms}} \cos \left(\theta_{r}+\frac{2}{3} \pi\right) \\
& \mathrm{B}_{16}=\mathrm{B}_{24}=\mathrm{B}_{35}=r_{r} L_{\mathrm{ms}} \cos \left(\theta_{r}-\frac{2}{3} \pi\right) \\
& \mathrm{B}_{42}=\mathrm{B}_{53}=\mathrm{B}_{61}=r_{s} L_{\mathrm{ms}} \cos \left(\theta_{r}+\frac{2}{3} \pi\right) \\
& \mathrm{B}_{43}=\mathrm{B}_{51}=\mathrm{B}_{62}=r_{s} L_{\mathrm{ms}} \cos \left(\theta_{r}-\frac{2}{3} \pi\right) \\
& \mathrm{C}_{12}=\mathrm{C}_{23}=\mathrm{C}_{31}=\mathrm{C}_{54}=\mathrm{C}_{65}=1.299 L_{m s}^{2} \omega_{r} \\
& \mathrm{C}_{13}=\mathrm{C}_{21}=\mathrm{C}_{32}=\mathrm{C}_{45}=\mathrm{C}_{56}=\mathrm{C}_{64}=-1.299 L_{m s}^{2} \omega_{r} \\
& \mathrm{C}_{14}=\mathrm{C}_{25}=\mathrm{C}_{36}=\mathrm{C}_{41}=\mathrm{C}_{52}=\mathrm{C}_{63}=L_{\Sigma m s} \omega_{r} \sin \theta_{r} \\
& \mathrm{C}_{16}=\mathrm{C}_{24}=\mathrm{C}_{35}=\mathrm{C}_{42}=\mathrm{C}_{53}=\mathrm{C}_{61}=L_{\Sigma m s} \omega_{r} \sin \left(\theta_{r}-\frac{2}{3} \pi\right) \\
& \mathrm{C}_{15}=\mathrm{C}_{26}=\mathrm{C}_{34}=\mathrm{C}_{43}=\mathrm{C}_{51}=\mathrm{C}_{62}=L_{\Sigma m s} \omega_{r} \sin \left(\theta_{r}+\frac{2}{3} \pi\right) \\
& \mathrm{D}_{11}=\mathrm{D}_{22}=\mathrm{D}_{33}=\mathrm{D}_{44}=\mathrm{D}_{55}=\mathrm{D}_{66}=2 L_{\mathrm{ms}}+L_{l r} \\
& \mathrm{D}_{16}=\mathrm{D}_{13}=\mathrm{D}_{65}=\frac{1}{2} L_{m s}=\mathrm{D}_{23}=\mathrm{D}_{31}=\mathrm{D}_{32}=\mathrm{D}_{45}=\mathrm{D}_{46}=\mathrm{D}_{54}=\mathrm{D}_{56} \\
& \mathrm{D}_{35}=\mathrm{D}_{42}=\mathrm{D}_{53}=\mathrm{D}_{61}=-L_{m s} \cos \left(\theta_{r}-\frac{2}{3} \pi\right)
\end{aligned}
$$

Dengan nilai $L_{\Sigma L}, L_{\Sigma m}$, dan $L_{\Sigma m s}$ seperti Persamaan (30) - (32)

$$
\begin{aligned}
& L_{\Sigma L}=\left(3 L_{m s}+L_{l r}^{\prime}\right) L_{l r}^{\prime} \\
& L_{\Sigma m}=2 L_{m s}+L_{l r}^{\prime} \\
& L_{\Sigma m s}=\frac{3}{2} L_{m s}^{2}+L_{m s} L_{l r}^{\prime}
\end{aligned}
$$

Putaran rotor dihitung menggunakan Persamaan (33) dan Persamaan (34)

$$
\frac{d \omega_{r}}{d t}=\frac{P}{2 J}\left(T_{e}-T_{L}\right)-\frac{B_{m}}{J} \omega_{r}
$$


Dengan

$$
\frac{d \theta_{r}}{d t}=\omega_{r}
$$

Torsi rotor dihitung menggunakan Persamaan (35)

$T_{e}=-\frac{P}{2} L_{m s}\left[\left(i_{a s} i_{a r}+i_{b s} i_{b r}+i_{c s} i_{c r}\right) \sin \theta_{r}+\left(i_{a s} i_{c r}+i_{b s} i_{a r}+i_{c s} i_{b r}\right) \sin \left(\theta_{r}-\frac{2}{3} \pi\right)+\left(i_{a s} i_{b r}+\right.\right.$
$\left.\left.i_{b s} i_{c r}+i_{c s} i_{a r}\right) \sin \left(\theta_{r}+\frac{2}{3} \pi\right)\right]$

\section{METODOLOGI PENYELESAIAN}

Secara umum, langkah-langkah penelitian dimulai dari ide dasar, studi literatur, perancangan, pembuatan dan pengujian software. Tahapan tersebut dijelaskan secara singkat sebagai berikut:

1. Gagasan/ide penelitian ini adalah mengimplementasikan metode penyelesaian persamaan model dinamik pada simulator motor induksi.

2. Studi pustaka, tahapan ini dilakukan melalui telaah literatur terhadap karya-karya yang dilakukan oleh peneliti sebelumnya khususnya berkaitan dengan simulator motor induksi, model dinamik motor induksi tiga fasa dan penyelesaian persaman diferensial secara numerik.

3. Perancangan software, merupakan tahapan pembuatan algoritma software ke dalam bentuk flowchart yang terdiri dari program simulasi motor listrik berbasis modul ODE15 dan metode Gear.

4. Realisasi software, merupakan tahapan pengkodean kedalam bentuk skrip Matlab dan skrip Phyton.

5. Pengujian software, tahapan ini terdiri dari dua tahap pengujian yaitu :

a. Tahapan pengujian software secara individual, tahapan ini dilakukan untuk meyakinkan algoritma Gear yang telah dibuat dapat menghasilkan solusi dari permasalahan persamaan deferensial. Algoritma tersebut diuji dengan menggunakan fungsi yang sederhana yang terdiri dari satu variabel bebas dan satu variabel terikat.

b. Tahapan pengujian software secara keseluruhan. Tahapan ini merupakan proses validasi software simulator motor induksi tiga fasa berbasis metode Gear dengan cara membandingkannya dengan hasil simulasi dengan Matlab berbasis ODE15. Parameter-parameter motor induksi yang dibandingkan adalah arus stator. Parameter-parameter tersebut akan diamati pada nilai maksimum, nilai minimum, waktu transisisi dan nilai peak-to-peak pada kondisi tunak.

\subsection{Program Simulasi Motor Listrik Berbasis ODE15}

ODE15 merupakan salah satu modul so/ver penyelesaian persamaan diferensial yang tersedia pada Matlab dan metode yang digunakan adalah Numerical Differentiation Formulas (NDF). Metode tersebut merupakan salah satu jenis metode $B D F$. Simulator motor induksi tiga fasa berbasis ODE15 dibuat dalam bentuk M-File dengan flowchart seperti pada Gambar 2 dan dijelaskan sebagai berikut:

1. Tetapkan nilai parameter-parameter motor seperti jumlah kutub $(P)$, resistansi belitan stator $\left(R_{s}\right)$, resistansi belitan rotor $\left(R_{r}\right)$, induktansi bersama stator-rotor $\left(L_{m s}\right)$, viscous Friction Coefficient $(\mathrm{Bm})$, momen inersia motor $(\mathrm{J})$, Torsi beban $\left(\mathrm{T}_{\mathrm{L}}\right)$, Tegangan stator $\left(U_{a s}, U_{b s}, U_{s c}\right)$, frekuensi (freq), tegangan rotor fasa-a $\left(u_{a r}\right)$, tegangan rotor fasa-b $\left(u_{b r}\right)$, tegangan rotor fasa-c $\left(\mathrm{u}_{\mathrm{cr}}\right)$.

2. Tetapkan nilai lama simulasi $\left(\mathrm{t}_{\mathrm{s}}\right)$, langkah simulasi $(\mathrm{h})$ dan awal simulasi $\left(\mathrm{t}_{0}\right)$. 
3. Hitung banyak data simulasi $m=\left(t_{s}+t_{0}\right) / h$.

4. Tetapkan nilai awal atau kondisi awal untuk arus, torsi beban, kecepatan dan sudut fasa (ias, ibso, ics, iaro, ibro, icro, $\theta_{0}, \mathrm{w}_{0}$ ).

5. Selesaikan persamaan deferensial (Persamaan (5) dan Persamaan (6) - (34)) menggunakan modul ODE15 yang tersedia pada Matlab.

6. Hitung torsi rotor Te menggunakan Persamaan (35).

7. Tampilkan hasilnya kedalam bentuk grafik.

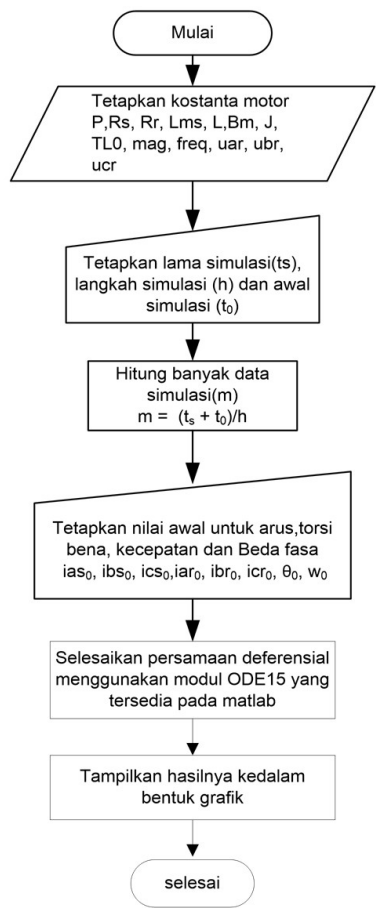

Gambar 2. Flowchart Simulator Motor Induksi Tiga Fasa Berbasis ODE15

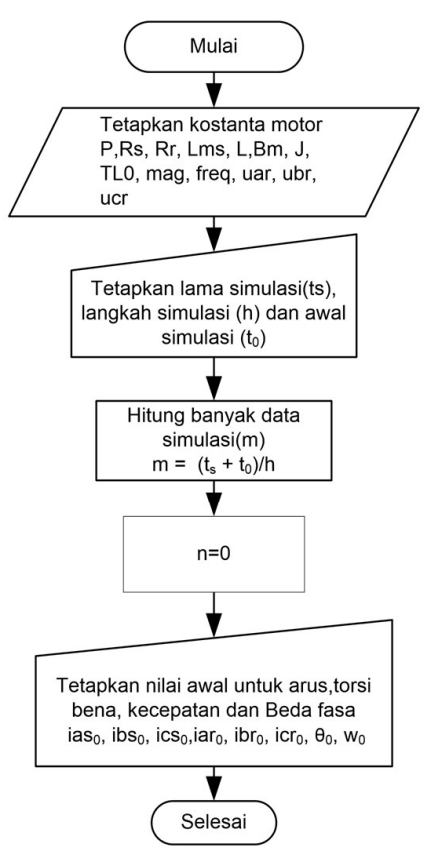

Gambar 3. Flowchart Penetapan Data awal Simulator Motor Induksi Tiga Fasa Berbasis Metode Gear

\subsection{Program Simulasi Motor Listrik Berbasis Metode Gear}

Metode penelitian dititikberatkan pada pembuatan simulator motor induksi tiga fasa yang meliputi metode Gear/BDF, Runge-Kutta orde empat, iterasi Gaus-Jacobi dan ODE15. Algoritma simulator berbasis metode Gear/BDFdibuat seperti pada Gambar 3 hingga 5 dengan bahasa pemograman Python. Model dinamik motor induksi yang digunakan seperti Persamaan (6) - (35). Penelitian ini menggunakan metode Gear/BDForde empat seperti Persamaan (1)(5) dan konstanta-konstantanya dapat dilhat pada Tabel 1. Metode Gear merupakan metode penyelesain persamaan deferensial yang tidak dapat self-starting. Oleh karena itu diperlukan suatu metode untuk membangkitkan data awal. Banyaknya data awal relatif terhadap jenis metode Gear yang digunakan. Penelitian ini memerlukan empat data awal dan metode yang digunakan untuk membangitkan data awal yaitu metode Runge-Kutta orde empat. Gear merupakan integrator implisit oleh karena itu penelitian ini menggunakan metode iterasi GausJacobi untuk menyelesaikan fungsi implisit pada metode Gear. Urutan proses pada Gambar 3 dan 4 dijelaskan sebagai berikut:

1. Tetapkan nilai parameter-parameter motor seperti jumlah kutub $(P)$, resistansi belitan stator $\left(R_{s}\right)$, resistansi belitan rotor $\left(R_{r}\right)$, induktansi bersama stator-rotor $\left(L_{m s}\right)$, viscous Friction Coefficient $(B m)$, momen inersia motor $(\mathrm{J})$, Torsi beban $\left(T_{\mathrm{L}}\right)$, Tegangan stator $\left(\mathrm{U}_{\mathrm{as}}, \mathrm{U}_{\mathrm{bs}}, \mathrm{U}_{\mathrm{sc}}\right)$, frekuensi (freq), tegangan rotor fasa-a $\left(\mathrm{u}_{\mathrm{ar}}\right)$, tegangan rotor fasa-b ( $\left.\mathrm{ubr}_{\mathrm{br}}\right)$, tegangan rotor fasa-c $\left(\mathrm{u}_{\mathrm{cr}}\right)$.

2. Tetapkan nilai lama simulasi (ts), langkah simulasi (h) dan awal simulasi ( $\left.\mathrm{t}_{0}\right)$. 
3. Hitung banyak data simulasi $m=\left(t_{s}+t_{0}\right) / h$.

4. Tetapkan nilai $\mathrm{n}$ sama dengan nol ( $\mathrm{n}$ adalah nomor/indeks data, indeks data dimulai dari nol).

5. Tetapkan nilai awal atau kondisi awal untuk arus, torsi dan kecepatan dan sudut fasa (ias $_{0}$, ibs $\left._{0}, \mathrm{ics}_{0}, \mathrm{iar}_{0}, \mathrm{ibr}_{0}, \mathrm{icr}_{0}, \theta_{0}, \mathrm{w}_{0}\right)$.

6. Selanjutnya menghitung/membangkitkan empat data awal menggunakan metode

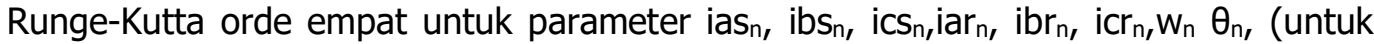
$n=0$ sampai dengan $n=3$ ). Proses ini bekerja jika $n<4$.

7. Jika $n>=4$, maka hitung data menggunakan metode Gear untuk parameter ias $\mathrm{s}_{\mathrm{n}} \mathrm{ibs}_{\mathrm{n}}$, $\mathrm{ics}_{\mathrm{n}}, \operatorname{iar}_{\mathrm{n}}, \mathrm{ibr}_{\mathrm{n}}, \mathrm{icr}_{\mathrm{n}}, \mathrm{w}_{\mathrm{n}} \theta_{\mathrm{n}}$. (n merupakan nomor/indek data).

8. Hitung torsi rotor Te menggunakan Persamaan (35).

9. Hitung variabel waktu $t_{n}$ dalam detik, $t_{n}=t_{n}+h$ ( $t_{n}$ adalah waktu pada data ke $n$ ).

10. Simpan nilai ias $s_{n}$, ibs $_{n}$, i $s_{n}$, iar $_{n}$, ibr $_{n}$, icr $_{n}, w_{n} \theta_{n}, \operatorname{Te}_{n}$ dan $t_{n}$.

11. Hitung $n=n+1$, tahapan ini bertugas untuk menaikan nomor/indek data.

12. Kembali ke langkah 7, jika batas simulasi belum tercapai $(n<m)$.

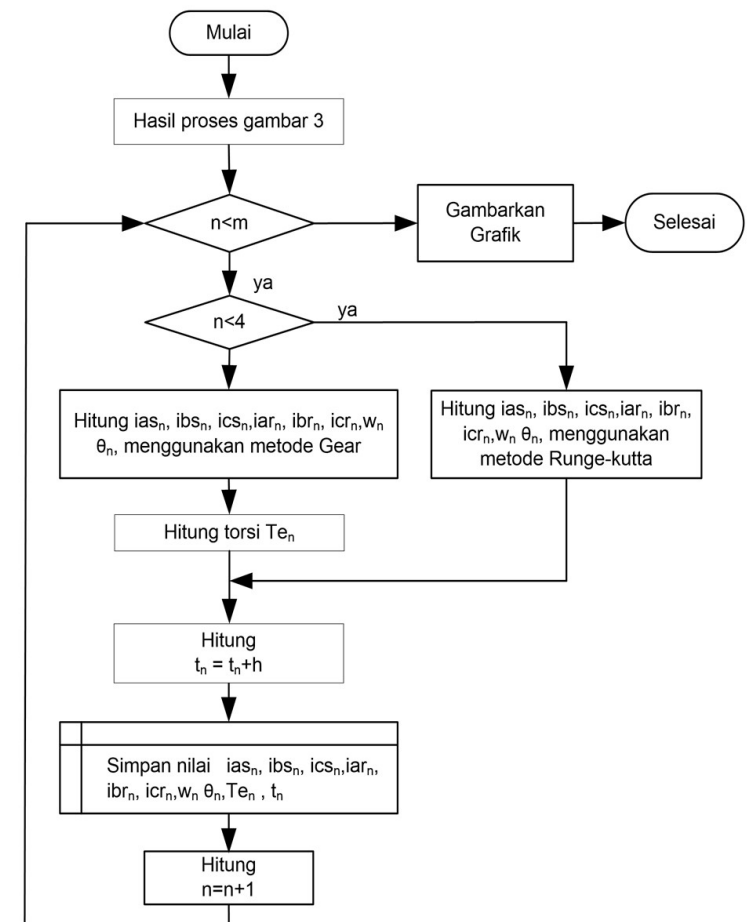

Gambar 4. Flowchart Pemrosesan Data Simulator Motor Induksi Tiga Fasa Berbasis Metode Gear

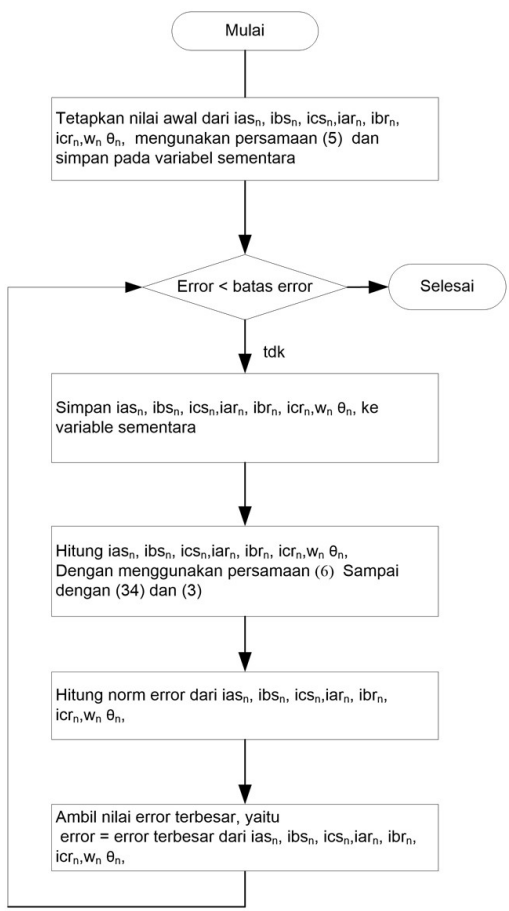

Gambar 5. Flowchart Menghitung ias $\mathrm{n}_{\text {, }}$ ibs $\mathrm{n}_{\mathrm{n}}$ ics $_{n}$, iar $_{n}$, ibr $_{n}$, icrn, $w_{n}$ dan $\theta_{n}$ menggunakan Metode Gear pada Gambar 4

Urutan proses pada Gambar 5 dijelaskan sebagai berikut :

1. Tetapkan/menghitung nilai/data awal dari ias $s_{n}, \operatorname{ibs}_{n}, \operatorname{ics}_{n}, \operatorname{iar}_{n}, \operatorname{ibr}_{n}, \operatorname{icr}_{n}, \mathbf{w}_{n}$, dan $\theta_{n}$. mengunakan Persamaan (5) dan Persamaan (6) sampai dengan Persamaan (34). Data awal ini merupakan nilai/data prediksi dari nilai/data ke-n dan dihitung berdasarkan empat data sebelumnya.

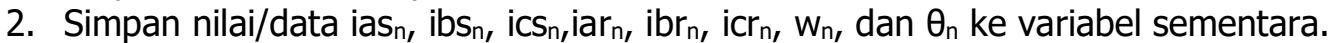

3. Selanjutnya menghitung data/nilai korektor dari iasn, ibs, ics $_{n}, \operatorname{iar}_{n}$, ibr $_{n}$, icr $_{n}, \mathbf{W}_{n}$ dan $\theta_{n}$ menggunakan Persamaan (3) dan Persamaan (6) sampai dengan Persamaan (34).

4. Hitung norm error dari iasn, ibs $s_{n}, \mathrm{ics}_{n}, \mathrm{iar}_{\mathrm{n}}, \mathrm{ibr}_{n}, \mathrm{icr}_{n}, \mathrm{w}_{\mathrm{n}}$, dan $\theta_{n}$. proses ini merupakan menghitung selisih absolut antara nilai sebulumnya dengan nilai saat ini. 
5. Ambil nilai norm error terbesar atau error $=$ errorterbesar dari ias $n_{n}$, ibs $_{n}$, ics ${ }_{n}$, iarn, ibr ${ }_{n}$, $\mathrm{icr}_{\mathrm{n}}, \mathrm{w}_{\mathrm{n}}$, dan $\theta_{\mathrm{nv}}$.

6. Jika error lebih besar dari batas error maka langkah ke 2 sampai dengan 5 diulang terus. Proses ini merupakan proses iterasi Gaus-Jacobi.

\section{HASIL DAN PEMBAHASAN}

Bagian ini memaparkan hasil simulasi motor induksi dengan menggunakan metode Gear dan ODE15. Waktu simulasi yang diterapkan nol sampai dengan dua detik dengan interval waktu 0,0001 detik dan kriteria errorpada iterasi Gaus-Jacobi sebesar 0,00001. Motor mulai dibebani ketika waktu lebih dari satu detik. Kondisi tersebut dianggap cukup untuk membandingkan hasil simulasi metode Gear dan ODE15, karena pada saat satu detik motor dapat mencapai keadaan tunak. Kondisi transien yang diamati adalah arus sesaat terbesar dan terkecil serta lama waktu transien. Sedangkan pada kondisi tunak yang diamati adalah arus peak-to-peak. Parameterparameter motor yang digunakan sebagai berikut:

1. Jumlah kutub 2

2. Resistansi belitan Stator $0,3 \Omega$

3. Resistansi belitan Rotor $0,2 \Omega$

4. Induktansi bersama/mutual Stator-Rotor $0,035 \mathrm{H}$

5. Induktansi bocor $0,003 \mathrm{H}$

6. Viscous Friction Coefficient 0,001

7. Momen inersia $0,02 \mathrm{~kg} \mathrm{~m}^{2}$

8. Torsi beban $40 \mathrm{~N}-\mathrm{m}$

9. Tegangan 220 volt (rms)

10. Frekuensi dari tegangan yang diterapkan $60 \mathrm{~Hz}$

\subsection{Hasil Simulasi Arus Stator Fasa-a}

Berdasarkan Gambar 6 dan 7 pada kondisi motor tidak berbeban menunjukkan pola grafik yang relatif identik untuk simulasi menggunakan metode Gear dan ODE15. Hasil perbandingan arus stator fasa-a dengan kondisi motor tidak berbeban dapat dilihat Tabel 2 dengan perbandingan arus sesaatnya sebagai berikut :

1. Simulasi menggunakan metode Gear menghasilkan arus sesaat tertinggi 150,22139 amper pada saat 0,0536 detik. Sedangakan ODE15 menghasilkan arus sesaat 150,25926 amper pada saat 0,0536 detik.

2. Simulasi menggunakan metode Gear menghasilkan arus sesaat terkecil $-155,47341$ amper pada saat 0,1286 detik. Sedangkan simulasi menggunakan ODE15 $-155,64565$ amper pada saat 0,0536 detik.

3. Ditinjau dari besarnya arus peak-to-peak pada kondisi tunak, simulasi menggunakan metode Gear sebesar 29,77505 amper dan 29,77323 amper untuk ODE15.

Perbandingan hasil simulasi arus stator fasa-a dengan kondisi motor berbeban, menunjukkan pola grafik yang relatif identik. Hasil perbandingan arus stator fasa-a dengan kondisi motor berbeban dapat dilihat juga pada Tabel 3 dengan perbandingan arus sesaatnya sebagai berikut:

1. Simulasi menggunakan metode Gear menghasilkan arus sesaat tertinggi 56,43329 amper pada saat 1,0346 detik. Sedangakn simulasi menggunakan ODE15 56,40591 amper pada saat 1,03460 detik.

2. Simulasi menggunakan metode Gear menghasilkan arus sesaat terkecil $-56,72026$ amper pada saat 1,043 detik. Sedangakan simulasi menggunakan ODE15 menghasilkan arus sesaat terkecil -55,88495 amper pada waktu 1,03460 detik. 
3. Ditinjau dari besarnya arus peak-to-peak pada kondisi tunak, simulasi menggunakan metode Gear sebesar 85,86374 amper dan 85,35201 amper untuk simulasi mengunakan ODE15.

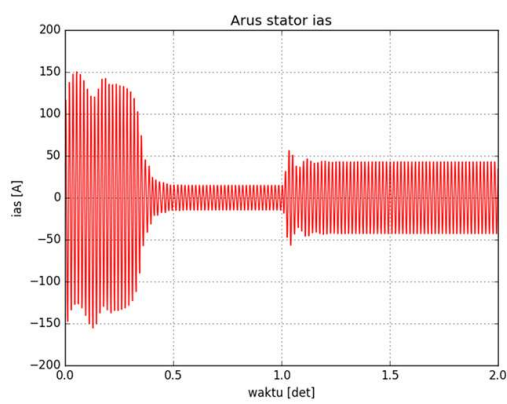

Gambar 6. Grafik Arus Stator Fasa-a Berbasis Metode Gear

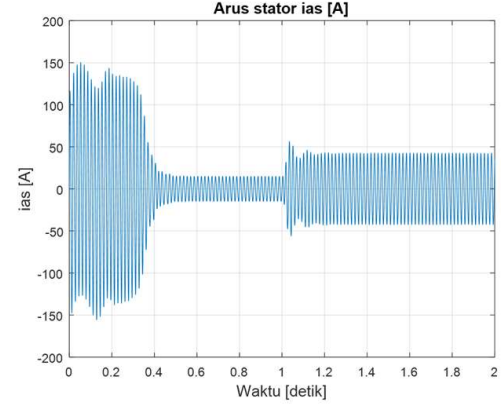

Gambar 7. Grafik Arus Stator Fasa-a Berbasis ODE15

Tabel 2. Perbandingan Hasil Simulasi Arus Stator Fasa-a Kondisi Motor Tidak Berbeban

\begin{tabular}{|c|c|c|c|c|}
\hline \multirow{2}{*}{ No } & \multirow{2}{*}{ Variabel } & \multicolumn{2}{|c|}{ Metode yang digunakan } & \multirow{2}{*}{$\begin{array}{c}\text { selisih absolut } \\
\text { [\%] }\end{array}$} \\
\hline & & Gear & ODE15 & \\
\hline 1 & Arus sesaat terbesar $[\mathrm{A}]$ & 150,22139 & 150,25926 & 0,0252 \\
\hline 2 & Arus sesaat terkecil $[\mathrm{A}]$ & $-155,47341$ & $-155,64565$ & 0,1107 \\
\hline 3 & Lama waktu transien [detik] & 0,50000 & 0,50000 & 0,0000 \\
\hline 4 & Arus peak-to-peak pada kondisi tunak [A] & 29,77505 & 29,77323 & 0,0061 \\
\hline
\end{tabular}

Tabel 3. Perbandingan Hasil Simulasi Arus Stator Fasa-a Kondisi Motor Berbeban

\begin{tabular}{|c|c|c|c|c|}
\hline \multirow{2}{*}{ No } & \multirow{2}{*}{ Variabel } & \multicolumn{2}{|c|}{$\begin{array}{c}\text { Metode yang } \\
\text { digunakan }\end{array}$} & \multirow{2}{*}{$\begin{array}{c}\text { selisih absolut } \\
\text { [\%] }\end{array}$} \\
\hline & & Gear & ODE15 & \\
\hline 1 & Arus sesaat terbesar $[\mathrm{A}]$ & 56,43329 & 56,40591 & 0,0485 \\
\hline 2 & Arus sesaat terkecil $[\mathrm{A}]$ & $-56,72026$ & $-55,88495$ & 1,4947 \\
\hline 3 & Lama waktu transien [detik] & 1,25000 & 1,25000 & 0,0000 \\
\hline 4 & Arus peak-to-peak pada kondisi tunak [A] & 85,86374 & 85,35201 & 0,5996 \\
\hline
\end{tabular}

\subsection{Hasil Simulasi Arus Stator Fasa-b}

Hasil simulasi dapat dilihat pada Gambar 8 dan 9, ditinjau secara visual kedua grafik tersebut dapat dikatakan polanya relatif mirip baik dalam kondisi berbeban maupun kondisi tidak berbeban. Perbandingan hasil simulasi menggunakn metode Gear dan ODE15 untuk kondisi motor tidak berbeban seperti Tabel 4 dan dijelaskan sebagai berikut:

1. Simulasi menggunakan metode Gear menghasilkan arus sesaat terbesar 200,79026 amper pada waktu 0,0089 detik. Sedangakan simulasi menggunakan ODE15 menghasilkan arus sesaat terbesar 200,78155 amper pada waktu 0,0089 detik.

2. Simulasi menggunakan metode Gear menghasilkan arus sesaat terkecil 147,29156 amper pada waktu 0,1674 detik. Sedangakn simulasi menggunakan ODE15 menghasilkan arus sesaat tertinggi $-148,08988$ pada waktu 0,1674 detik.

3. Ditinjau dari besarnya arus peak-to-peak pada kondisi tunak, simulasi menggunakan metode Gear memiliki arus peak-to-peak sebesar 29,77516 amper dan 29,77328 amper untuk simulasi mengunakan ODE15. 


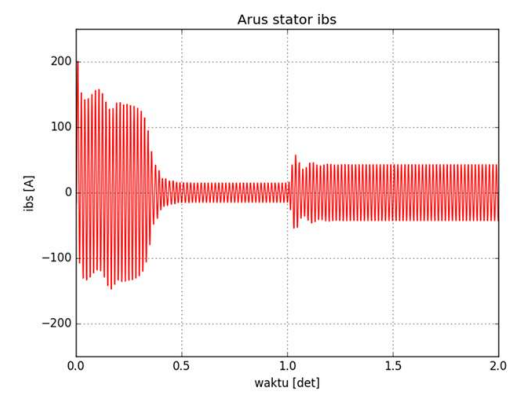

Gambar 8. Grafik Arus Stator Fasa-b Berbasis Metode Gear

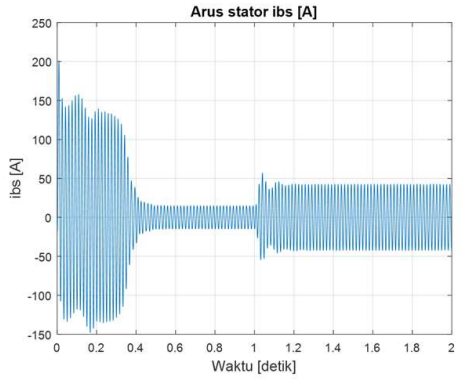

Gambar 9. Grafik Arus Stator Fasa-b Berbasis ODE15

Tabel 4. Perbandingan Hasil Simulasi Arus Stator Fasa-b Kondisi Motor Tidak Berbeban

\begin{tabular}{|c|c|c|c|c|}
\hline \multirow{2}{*}{ No } & \multirow{2}{*}{ Variabel } & \multicolumn{2}{|c|}{ Metode yang digunakan } & \multirow{2}{*}{$\begin{array}{c}\text { selisih absolut } \\
\text { [\%] }\end{array}$} \\
\hline & & Gear & ODE15 & \\
\hline 1 & Arus sesaat terbesar $[\mathrm{A}]$ & 200,79026 & 200,78155 & 0,0043 \\
\hline 2 & Arus sesaat terkecil $[\mathrm{A}]$ & $-147,29156$ & $-148,08988$ & 0,5391 \\
\hline 3 & Lama waktu transien [detik] & 0,50000 & 0,50000 & 0,0000 \\
\hline 4 & Arus peak-to-peak pada kondisi tunak [A] & 29,77516 & 29,77328 & 0,0063 \\
\hline
\end{tabular}

Perbandingan hasil simulasi arus stator fasa-b dengan kondisi motor berbeban dapat dilihat pada Tabel 5 dengan uraian sebagai berikut :

1. Simulasi menggunakan metode Gear menghasilkan arus sesaat terbesar 57,5314 amper pada waktu 1,0402 detik. Sedangakan simulasi menggunakan ODE15 menghasilkan arus sesaat terbesar 57,00639 amper pada waktu 1,0402 detik.

2. Simulasi menggunakan metode Gear menghasilkan arus sesaat terkecil $-54,36661$ amper pada waktu 1,0318 detik. Sedangakn simulasi menggunakan ODE15 menghasilkan arus sesaat tertinggi $-54,38813$ amper pada waktu 1,0318 detik.

3. Ditinjau dari besarnya arus peak-to-peak pada kondisi tunak, simulasi menggunakan metode Gear memiliki arus peak-to-peak sebesar 85,86116 amper dan 85,35796 amper untuk simulasi mengunakan ODE15.

Tabel 5. Perbandingan Hasil Simulasi Arus Stator Fasa-b Kondisi Motor Berbeban

\begin{tabular}{|c|c|c|c|c|}
\hline \multirow[t]{2}{*}{ No } & \multirow[t]{2}{*}{ Variabel } & \multicolumn{2}{|c|}{$\begin{array}{c}\text { Metode yang } \\
\text { digunakan }\end{array}$} & \multirow{2}{*}{$\begin{array}{c}\text { selisih absolut } \\
{[\%]}\end{array}$} \\
\hline & & Gear & ODE15 & \\
\hline 1 & Arus sesaat terbesar $[\mathrm{A}]$ & 57,53140 & 57,00639 & 0,9210 \\
\hline 2 & Arus sesaat terkecil $[\mathrm{A}]$ & $-54,36661$ & $-54,38813$ & 0,0396 \\
\hline 3 & Lama waktu transien [detik] & 1,25000 & 1,25000 & 0,0000 \\
\hline 4 & Arus peak-to-peak pada kondisi tunak [A] & 85,86116 & 85,35796 & 0,5895 \\
\hline
\end{tabular}

\subsection{Hasil Simulasi Arus Stator Fasa-c}

Tabel 6 merupakan hasil perbandingan pada kondisi motor tidak berbeban berdasarkan Gambar 10 dan 11. Ditinjau dari besaraan arus sesaatnya dijelaskan sebagai berikut:

1. Simulasi menggunakan metode Gear menghasilkan arus sesaat tertinggi 151,60294 amper pada waktu 0,148 detik. Sedangakan simulasi menggunakan ODE15 menghasilkan arus sesaat terbesar 151,39062 amper pada waktu 0,148 detik. 
2. Simulasi menggunakan metode Gear menghasilkan arus sesaat terkecil $-199,48249$ amper pada waktu 0,00610 detik. Sedangakan simulasi menggunakan ODE15 menghasilkan arus sesaat tertinggi $-199,47845$ amper pada waktu 0,0061 detik.

3. Ditinjau dari besarnya arus peak-to-peak pada kondisi tunak, simulasi menggunakan metode Gear memiliki arus peak-to-peak sebesar 29,77473 amper dan 29,77293 amper untuk simulasi mengunakan ODE15.

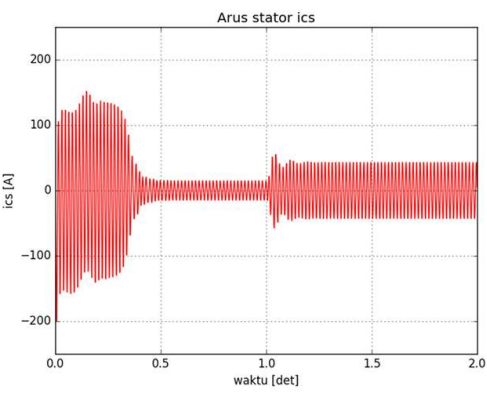

Gambar 10. Grafik Arus Stator Fasa-c Berbasis Metode Gear

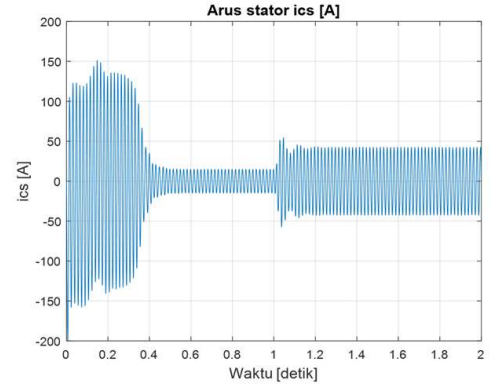

Gambar 11. Grafik Arus Stator Fasa-c Berbasis ODE15

Tabel 7 merupakan hasil perbandingan pada kondisi motor berbeban berdasarkan Gambar 10 dan 11. Ditinjau dari besaraan arus sesaatnya dijelaskan sebagai berikut:

1. Simulasi menggunakan metode Gear menghasilkan arus sesaat tertinggi 55,21390 amper pada saat 1,0458 detik. Sedangakan simulasi menggunakan ODE15 menghasilkan arus sesaat terbesar 54,43978 amper pada saat 1,0458 detik

2. Simulasi menggunakan metode Gear menghasilkan arus sesaat terkecil $-57,47451$ amper pada saat 1,0374 detik. Sedangakan simulasi menggunakan ODE15 menghasilkan arus sesaat tertinggi -57,27368 amper pada waktu 1,0374 detik.

3. Ditinjau dari besarnya arus peak-to-peak pada kondisi tunak, simulasi menggunakan metode Gear memiliki arus peak-to-peak sebesar 85,86336 amper dan 85,33914 amper untuk simulasi mengunakan ODE15.

Tabel 6. Perbandingan Hasil Simulasi Arus Stator Fasa-c Kondisi Motor Tidak Berbeban

\begin{tabular}{|c|c|c|c|c|}
\hline \multirow{2}{*}{ No } & \multirow{2}{*}{ Variabel } & \multicolumn{2}{|c|}{ Metode yang digunakan } & \multirow{2}{*}{$\begin{array}{c}\text { selisih absolut } \\
{[\%]}\end{array}$} \\
\hline & & Gear & ODE15 & \\
\hline 1 & Arus sesaat terbesar $[\mathrm{A}]$ & 151,60294 & 151,39062 & 0,1402 \\
\hline 2 & Arus sesaat terkecil $[\mathrm{A}]$ & $-199,48249$ & $-199,47845$ & 0,0020 \\
\hline 3 & Lama waktu transien (detik) & 0,50000 & 0,50000 & 0,0000 \\
\hline 4 & Arus peak-to-peak pada kondisi tunak [A] & 29,77473 & 29,77293 & 0,0060 \\
\hline
\end{tabular}

Tabel 7. Perbandingan Hasil Simulasi Arus Stator Fasa-c Kondisi Motor Berbeban

\begin{tabular}{|c|c|c|c|c|}
\hline \multirow[t]{2}{*}{ No } & \multirow{2}{*}{ Variabel } & \multicolumn{2}{|c|}{$\begin{array}{c}\text { Metode yang } \\
\text { digunakan }\end{array}$} & \multirow{2}{*}{$\begin{array}{c}\text { selisih absolut } \\
\text { [\%] }\end{array}$} \\
\hline & & Gear & ODE15 & \\
\hline 1 & Arus sesaat terbesar $[\mathrm{A}]$ & 55,21390 & 54,43978 & 1,4220 \\
\hline 2 & Arus sesaat terkecil $[\mathrm{A}]$ & $-57,47451$ & $-57,27368$ & 0,3506 \\
\hline 3 & Lama waktu transien [detik] & 1,25000 & 1,25000 & 0,0000 \\
\hline 4 & Arus peak-to-peak pada kondisi tunak [A] & 85,86336 & 85,33914 & 0,6143 \\
\hline
\end{tabular}

4.4 Diskusi Hasil Simulasi Arus Stator

Berdasarkan Tabel 2 sampai dengan 7, diperoleh perbedaan terbesar yaitu berturut-turut $1,4947 \%, 0,9210 \%$ dan 1,4220 \% masing-masing untuk arus stator fasa-a, fasa-b dan fasa- 
c. Selain itu, perbedaan hasil simulasi arus stator antara metode Gear dan ODE15 dapat dilihat seperti Tabel 8. Terjadinya perbedaan hasil simulasi tersebut disebabkan adanya perbedaan nilai data awal yang dibangkitkan dan perbedaan orde dari metode Gear yang digunakan. Perbedaan nilai data awal tersebut dipengaruhi oleh metode penyelesaian persamaan diferensial yang digunakan sehingga menyebabkan nilai truncation-error yang berbeda. Berdasarkan Gambar 6 sampai dengan 11, perbedaan rata-rata nilai data awal antara metode ODE15 dan Gear yaitu 0,0016\%.

Tabel 8. Perbedaan Hasil Simulasi Arus Stator antara Metode Gear dan ODE15

\begin{tabular}{|c|l|c|c|c|c|}
\hline \multirow{2}{*}{ No } & \multicolumn{1}{|c|}{ Variabel } & \multicolumn{2}{|c|}{ Perbedaan Rata-rata [\%] } & Perbedaan \\
\cline { 3 - 5 } & & $\begin{array}{c}\text { Kondisi } \\
\text { motor tidak } \\
\text { berbeban }\end{array}$ & $\begin{array}{c}\text { Kondisi } \\
\text { motor } \\
\text { berbeban }\end{array}$ & $\begin{array}{c}\text { Semua fasa } \\
\text { dan kondisi }\end{array}$ & $\begin{array}{c}\text { fasa dan } \\
\text { kondisi [\%] }\end{array}$ \\
\hline 1 & Arus sesaat terbesar & 0,0566 & 0,7972 & 0,4269 & 1,4220 \\
\hline 2 & Arus sesaat terkecil & 0,2173 & 0,6283 & 0,4228 & 1,4947 \\
\hline 3 & Lama waktu transien & 0,0000 & 0,0000 & 0,0000 & 0,0000 \\
\hline 4 & $\begin{array}{l}\text { Arus peak-to-peak pada } \\
\text { kondisi tunak }\end{array}$ & 0,0061 & 0,6011 & 0,3036 & 0,6143 \\
\hline
\end{tabular}

\section{KESIMPULAN}

Simulator motor induksi tiga fasa yang dibuat dapat menyimulasikan perilaku dinamik motor induksi tiga fasa dengan baik, sesuai hasil simulasi menggunakan modul ODE15 dengan perbedaan $1,5 \%, 0,93 \%$ dan $1,5 \%$ secara berturut-turut untuk arus stator fasa-a, arus stator fasa-b dan arus stator fasa-c.

\section{DAFTAR RUJUKAN}

Aleck, W. L. (2017). Simulink/MATLAB Dynamic Induction Motor Model For Use As A Teaching And Research Tool. International Journal Of Soft Computing And Engineering (IJSCE), 3(4), 102-107.

Bélanger, J., \& Paquin, J.-N. (2010). The What, Where And Why of Real-Time Simulation. Planet Rt, 1(1), 25-29.

Boldea, I., Tutelea, L., \& Klumpner, C. (2001). Artificial Loading Of Induction Machines: A Review. In Workshop On Electrical Machines Parameters, 9-14.

Boora, S., Agarwal, S., \& Sandhu, K. (2013). Dynamic Dq Axis Modeling Of Three-Phase Asynchronous Machine Using Matlab. International Journal Of Advanced Research In Electrical, Electronics And Instrumentation Engineering, 2(8), 3942-3951.

Dorjsuren, Y., Tumenbayar, L., \& J.Tsevegmid. (2015). Three-Axis Dynamic Modeling Of Induction Motor. International Journal Of Mathematical Models and Methods In Applied Sciences, 9, 527-536.

Esfandiari, R. S. (2017). Numerical Methods For Engineers And Scientists Using MATLABR. Florida: Crc Press. 
Griffiths, G. W. (2016). Numerical Analysis Using R. United Kingdom: Cambridge University Press.

Kocabas, D. A., Salman, E., \& Atalay, A. K. (2011). Analysis Using DQ Transformation Of A Drive System Including Load And Two Identical Induction Motors. In 2011 IEEE International Electric Machines \& Drives Conference (IEMDC) (ppl. 1575-1578).

Kulikov, G. Y. (2013). Cheap Global Error Estimation In Some Runge-Kutta Pairs. IMA Journal of Numerical Analysis, 33(1), 136-163.

Lyshevski, S. E. (2008). Ectromechanical Systems And Devices. Florida: CRC Press.

Menghal, P. M., \& Laxmi, A. J. (2014). Dynamic Modeling, Simulation \& Analysis Of Induction Motor Drives. International Conference on Science Engineering and Management Research (ICSEMR) (pp. 1-7).

Mulyono, N., \& Septiyanto, D. (2018). Implementasi Pemodelan Arus Dan Putaran Motor Induksi Tiga Fasa Dengan Metode Runge-Kutta Orde Empat Berbasis Rashberry PI. Industrial Research Workshop And National Seminar, 9, hal. 386-395. Bandung.

Omale, D., Ojih, P. B., \& Ogwo, M. O. (2014). Mathematical Analysis Of Stiff And Non-Stiff Initial Value Problems Of Ordinary Differential Equation Using Matlab. International Journal Of Scientific \& Engineering Research, 49-59.

Phukon, L. J., \& Baruah, N. (2015). Generalized Matlab Simulink Model Of A Three Phase Induction Motor. International Journal Of Innovative Research In Science, Engineering And Technology, 4(5), 2926-2934.

Rahmouni, W., \& Benasla, L. (2017). Transient Stability Analysis Of The IEEE 39-Bus Power System Using Gear And Block Methods. In 2017 5th International Conference On Electrical Engineering-Boumerdes (ICEE-B) (pp. 1-6).

Rath, G., Harker, M., \& Zaev, E. (2017). Direct Numerical Solution Of Stiff ODE Systems In Optimal Control. In 2017 6th Mediterranean Conference On Embedded Computing (MECO) (pp. 1-5).

Shampine, L. F., \& Reichhel, M. W. (1997). The Matlab Ode Suite. SIAM Journal On Scientific Computing, 18(1), 1-22.

Shampine, L. F., Watfs, H. A., \& Davenport, S. M. (1979). Solving Nonstiff Ordinary Differential Equations-The State of The Art. SIAM Journal On Scientific Computing, 18(3), 376411. 